\title{
A new species and first record of Dracoderes (Kinorhyncha: Allomalorhagida: Dracoderidae) from American waters, with an identification key of the genus
}

\author{
Cepeda Diego ${ }^{1,{ }^{*}}$, Pardos Fernando ${ }^{1}$, Sánchez Nuria ${ }^{1,2}$
}

\begin{abstract}
1 Departamento de Biodiversidad, Ecología y Evolución, Facultad de Ciencias Biológicas, Universidad Complutense de Madrid, José Antonio Novais St. 12, 28040, Madrid, Spain

${ }^{2}$ Laboratoire Environnement Profond, Institut Français de Recherche pour l'Exploitation de la Mer (IFREMER), Centre Bretagne - ZI de la Pointe du Diable, CS 10070 - 29280, Plouzané, France

*Corresponding author : Diego Cepeda, email address : diegocepeda@ucm.es
\end{abstract}

\begin{abstract}
:
A new species of Dracoderes, D. spyro sp. nov., is described from Hispaniola Island (Caribbean Sea), and represents the first record of this genus in American waters. The new species is distinguished from its congeners by the presence of lateroventral spines on segments 3-4 and 6-9, lateral accessory spines on segment 5, lateroventral tubes on segments 2,5 and 10, and laterodorsal tubes on segment 8. Additionally, a dichotomous key to the species level for the genus Dracoderes is included.
\end{abstract}

Keywords : Taxonomy, Morphology, Caribbean Sea, Dominican Republic, Haiti, Kinorhynchs 


\section{Introduction}

The phylum Kinorhyncha comprises a group of meiofaunal, holobenthic, free-living organisms that inhabit the upper centimetres of sandy and muddy marine soft bottoms (Neuhaus, 2013; Sørensen and Pardos, 2008). Until recently, the phylum was composed of two orders, Cyclorhagida and Homalorhagida, (Higgins, 1964; Zelinka, 1896) comprising 23 genera (Dal Zotto et al. 2013; Sánchez et al. 2014; Sørensen, 2013). However, more recent analyses, based on either ribosomal genes, or ribosomal genes combined with morphology, indicated the paraphyly of Cyclorhagida, as the former cyclorhagid genus Dracoderes Higgins and Shirayama, 1990 turned out to be more closely related with homalorhagid taxa (Dal Zotto et al. 2013; Sørensen et al. 2015; Yamasaki et al. 2013). As a result, the systematics of the phylum were modified, accommodating the family Dracoderidae within the new class Allomalorhagida, together with the former homalorhagid taxa and the recently established genus Franciscideres Dal Zotto et al., 2013 (Sørensen et al. 2015).

Kinorhynchs spend their whole life cycle in the sediment, have a limited locomotion and are gonochoristic. Thus, kinorhynch species have been considered to usually show regional distribution patterns limited to a few hundreds of kilometres (Artois et al. 2011; Kozloff, 1972; Yamasaki et al. 2014). Nevertheless, unequal species richness and biogeographical distribution patterns may be found among kinorhynch species by focusing on upper taxonomic categories such as genera or families (Neuhaus, 2013; Sørensen et al. 2012). Thus, there are some highly diverse taxa, e.g., the genus Echinoderes Claparède, 1863 and the family Pycnophyidae, that are distributed worldwide and together represents more than two thirds of the total number of known kinorhynch species. On the contrary, other taxa display much more restricted biogeographical distributions and are composed of a single or a few species, e.g., the monotypic Polacanthoderes Sørensen, 2008 only known from the South Shetland Archipelago in the Antarctic Ocean (Sørensen, 2008) or Neocentrophyes Higgins, 1969 composed of two species restricted to the Indian Ocean (Higgins, 1969). This was also the case of the genus Dracoderes that appeared to have a distribution limited to the Seto Inland Sea and the Sea of Japan until the description of a new species from the Atlantic coast of Spain (Sørensen et al. 2012).

Dracoderes currently accommodates six species, five from the northwestern Pacific Ocean, namely D. abei Higgins and Shirayama, 1990 (Seto Inland Sea, Sea of 
61 Japan and northwest Pacific); D. nidhug Thomsen et al., 2013 (Korea, Sea of Japan); D.

62 orientalis Adrianov, 1999 in Adrianov and Malakhov, 1999 (Korea, Sea of Japan); D. snufkini Yamasaki, 2015 (Okinawa, East China Sea); and D. toyoshioae Yamasaki, 2015 (Okinawa, East China Sea); and one from Galicia at the Atlantic coast of Spain: D. gallaicus Sørensen et al., 2012. The genus is morphologically characterized by a combination of mouth cone with nine outer oral styles alternating in size, neck with nine placids dorsal and midlaterally interrupted by cuticular foldings, cuticle of first segment as a closed ring, cuticle of remaining segments divided into one tergal and two sternal plates, dorsal spines on at least segments 3-9 with the anteriormorst spine middorsally located, following ones in paradorsal position alternatingly displaced left or right regarding to the middorsal line and posteriormost spine middorsal or paradorsally located, and lateroventral spines on at least segments 6-9 (Higgins and Shirayama, 1990; Sørensen et al. 2012; Yamasaki, 2015). The most significant morphological differences among species of Dracoderes are the position of tubes and dorsal spines, the shape and size of trunk segments, the shape of pectinate fringe and the shape of tergal extensions (Sørensen et al. 2012; Thomsen et al. 2013; Yamasaki, 2015). There is also sexual dimorphism in Dracoderes, as males possess three pairs of penile spines on segment 11 (Sørensen et al. 2012).

Samples of meiofauna from the Caribbean Sea and adjacent waters collected by Dr R. P. Higgins in 1976 and 1980 and deposited in the Smithsonian National Museum of Natural History of Washington (NMNH) gave the authors the opportunity to study several specimens of Dracoderes from Hispaniola Island, the second largest land mass of the Greater Antilles after Cuba, where kinorhynchs have been scarcely studied. There are few papers dealing with the biodiversity of this phylum in the Caribbean Sea (Higgins, 1983; Kirsteuer, 1964; Neuhaus et al. 2014; Pardos et al. 2016; Sørensen, 2006). The present study contributes to the understanding of the taxonomy and biogeographical distribution of the allomalorhagid Dracoderes as well as to the knowledge of kinorhynch biodiversity of the Caribbean Sea and adjacent waters.

\section{Material and methods}

The studied specimens of Dracoderes were collected at four different localities in Hispaniola Island, Caribbean Sea (western Atlantic Ocean). Detailed information on the 
93 localities and sampling data are summarized in Fig. 1A-C and Table 1. Samplings were

94 performed using a meiobenthic dredge (Higgins, 1988). After sampling, meiofauna was 95 extracted from sediment using the bubble and blot method defined by Higgins (1964).

96 Meiofaunal specimens were fixed in $4 \%$ formalin and then preserved in Carosafe ${ }^{\circledR}$ or

$97 \quad 70 \%$ ethanol.

The fixed kinorhynchs were picked up under a Motic ${ }^{\circledR}$ SMZ-168 stereo zoom microscope with the help of an Irwin loop. Initially, specimens were washed with distilled water in order to remove formalin. For light microscopy (LM), specimens were dehydrated through a graded series of $25 \%, 50 \%, 75 \%$ and $100 \%$ glycerin and finally mounted on a glass slide or a Cobb's aluminium slide holder in Fluoromount $G^{\circledR}$ and sealed with Depex ${ }^{\circledR}$. The mounted specimens were studied and photographed using an Olympus ${ }^{\circledR}$ BX51-P microscope with differential interference contrast (DIC) optics equipped with an Olympus ${ }^{\circledR}$ DP-70 camera. Measurements were obtained with Olympus cellSens ${ }^{\circledR}$ software. The identification at genus level of the specimens was done according to the dichotomous key provided by Sørensen and Pardos (2008). For scanning electron microscopy (SEM), specimens were dehydrated through a graded series of $80 \%, 90 \%, 95 \%$ and $100 \%$ ethanol. Then, specimens were cleaned by an ultrasonic cleaner for $10-15 \mathrm{~s}$, transferred to acetone and critical point dried. Finally, the kinorhynchs were mounted on aluminium stubs, coated with gold and examined with a JSM $^{\circledR}$ 6335-F JEOL SEM in the ICTS Centro Nacional de Microscopía Electrónica (Universidad Complutense de Madrid, Spain). Images and line drawing were mounted using Adobe ${ }^{\circledR}$ Photoshop 6.0 and Illustrator CC-2014 software.

\section{Results}

\section{Taxonomic account}

Class Allomalorhagida Sørensen et al., 2015

Family Dracoderidae Higgins and Shirayama, 1990

Genus Dracoderes Higgins and Shirayama, 1990

\section{Dracoderes spyro sp. nov.}

urn:lsid:zoobank.org:act:1C598D96-958E-4A3D-82A7-3E07270089F9 
123 (Figs. 2-4 and Tables 2-3)

124

125

126

127

128

129

130

131

132

133

134

135

136

137

138

139

\subsection{Type material}

Holotype, adult female, collected on 10 November 1980 at Cabo Haitiano, Haiti, Hispaniola Island, western Atlantic Ocean: $19^{\circ} 46^{\prime} 12^{\prime \prime} \mathrm{N}, 072^{\circ} 11^{\prime} 00^{\prime} \mathrm{W}$ (L4) (Fig. 1C) at 3-5 $\mathrm{m}$ depth in mud; mounted in Fluoromount $\mathrm{G}^{\circledR}$, deposited at NMNH under accession number: USNM1480327. Paratypes, six adult females and five males; three of them with same collecting data as holotype, mounted in Fluoromount $G^{\circledR}$, deposited at NMNH under accession numbers: USNM1480328, USNM1480329, USNM1480333; two of them collected on 02 November 1980 at Puerto Plata, Dominican Republic, Hispaniola Island, western Atlantic Ocean: $19^{\circ} 48^{\prime} 12^{\prime} \mathrm{N}, 070^{\circ} 42^{\prime} 00^{\prime} \mathrm{W}$ (L1) (Fig. 1C) at $5 \mathrm{~m}$ depth in sandy mud, mounted in Fluoromount $\mathrm{G}^{\circledR}$, deposited at NMNH under accession numbers: USNM1480330, USNM1480334; two of them collected on 04 November 1980 at Isabela Bay, Dominican Republic, Hispaniola Island, western Atlantic Ocean: $19^{\circ} 53^{\prime} 18^{\prime \prime} \mathrm{N}, 071^{\circ} 05^{\prime} 36^{\prime \prime} \mathrm{W}$ (L3) (Fig. 1C) at $4 \mathrm{~m}$ depth in silty mud, mounted in Fluoromount $\mathrm{G}^{\circledR}$, deposited at NMNH under accession numbers: USNM1480331, USNM1480335; two of them collected on 03 November 1980 at Puerto Blanco, Dominican Republic, Hispaniola Island, western Atlantic Ocean: $19^{\circ} 54^{\prime} 24^{\prime \prime} \mathrm{N}, 070^{\circ} 56^{\prime} 24^{\prime \prime} \mathrm{W}$ (L2) (Fig. 1C) at $3 \mathrm{~m}$ depth in silty mud, mounted in Fluoromount $\mathrm{G}^{\circledR}$, deposited at NMNH under accession numbers: USNM1480332, USNM1480336; two of them collected on 15 March 1976 at Puerto Príncipe, Haiti, Hispaniola Island, western Atlantic Ocean: $18^{\circ} 32^{\prime} 21^{\prime \prime} \mathrm{N}, 072^{\circ} 20^{\prime} 05^{\prime \prime} \mathrm{W}$ (L5) (Fig. 1C) at $5 \mathrm{~m}$ depth in mud, mounted in Fluoromount $\mathrm{G}^{\circledR}$, deposited at NMNH under accession numbers: USNM1480337, USNM1480338.

\subsection{Non-type material}

159 additional specimens from all the previous localities, mounted for LM, deposited at NMNH under accession numbers USNM1480339-USNM1480496; and 3 additional specimens mounted for SEM and stored at the Invertebrates Collection of the Meiofaunal Laboratory of the Universidad Complutense de Madrid (UCM), Spain.

\subsection{Diagnosis}


152 Dracoderes with middorsal spines on segments 2 and 9, paradorsal spines on segments

$1533-8$, lateroventral spines on segments 3-4 and 6-9, lateral accessory spines on segment

1545 , lateroventral tubes on segments 2, 5 and 10 and laterodorsal tubes on segment 8.

155

156

157

158

159

160

161

162

163

164

165

166

167

168

169

170

171

172

173

174

175

176

177

178

179

180

181

182

\subsection{Etymology}

The species is named after the dragon "Spyro", the main character of the platform video games series Spyro the Dragon ${ }^{\mathrm{TM}}$, originally released by the defunct Universal Interactive Studios.

\subsection{Description}

See Table 2 for measurements and dimensions, and Table 3 for summary of spine, tube, nephridiopore and sensory spot locations.

Head consists of retractable mouth cone and introvert (Figs. 2A-B, D and 4A-C). Internal part of mouth cone with three rings of inner oral styles. Exact number, arrangement and morphology of inner oral styles not determined. External part of mouth cone with 9 outer oral styles (Fig. 2B). Outer oral styles alternate in size between longer and shorter ones. Five long styles appear anterior to the odd numbered introvert sections, whereas four shorter ones appear anterior to the even numbered ones, except in the middorsal section 6 where a style is missing. Both longer and shorter styles with two jointed subunits, terminating into a hook-like structure, and a basis with lateral, pectinate fringes and a widened median area with bushy fringe tips (Fig. 2B). Introvert with seven rings of scalids. Scalids with a long distal part and a shorter basal sheath. Basal sheath laterally extending into long, filiform fringes (Figs. 2D and 4C). Nine trichoscalids (Figs. 2D and 4C) distributed as single ones in sections 2, 4, 6, 8 and 10, and as paired ones in sections 5 and 7. Exact number, arrangement and detailed morphology of scalids not determined as they tended to be collapsed when mounted, so further examination was not possible.

Neck with nine placids and a distinct joint between the neck and segment 1 (Figs. 2C and 3A-B); midventral and midlateral placids wider (17 $\mu \mathrm{m}$ wide at base) than others (10-14 $\mu \mathrm{m}$ wide at base). Ventral placids close each other; subdorsal, laterodorsal and midlateral placids separated by cuticular folds (Figs. 2C and 3A-B).

Trunk with eleven segments (Figs. 2A, 3A-B and 4A-B); segment 1 consists of closed cuticular ring; segments 2-11 consist of one tergal and two sternal plates (Figs. 
2A, 3A-B and 4A-B). Tergosternal junctions intracuticular (only visible with LM) (Fig. 2F). Midsternal junctions externally visible as conspicuous lines in both LM and SEM (Figs. 2F, 3B and 4B, F-G). Cuticle of segments 1-8 with longitudinal ridges in dorsal, lateral and ventral areas (Figs. 2A, E, 3A-B and 4A-B, D, F-G, I). Tergal anterior plates middorsally bulging; posterior ones flattened, with tapering outline in lateral view (Fig. 4B). Sternal plates widest at segment 5, but almost constant in width throughout the trunk, tapering at the last trunk segments (Figs. 2A, F, 3A-B and 4B). Sternal plates relatively (MSW-5:TL average ratio $=30.5 \%)$, giving the animal a plump general appearance (Figs. 2A, 3A-B and 4A-B). Cuticular hairs absent (except on sternal plates of segment 11). Posterior margin of segments 1-2 serrated, with a convex midventral Vshaped extension and rounded indentations without serrated edges in the lateroventral position (Figs. 2E-F, 3A-B and 4F); posterior margin of remaining segments strongly serrated without $\mathrm{V}$-shaped extension, with rounded indentations without serrated edges in the lateroventral position (Figs. 2E, F, 3A-B and 4A-B, F-G). Well-developed pectinate fringes absent.

Segment 1 without spines or tubes. Pair of sensory spots in ventrolateral and ventromedial positions, two pairs of sensory spots in subdorsal and laterodorsal positions (Fig. 3A-B); sensory spots on this and remaining segments small, rounded, with a ring of cuticular papillae surrounding a central pore (Fig. 4I).

Segment 2 with middorsal spine (Figs. 2E, 3A and 4A, D); dorsal spines on this and remaining segments thin and acicular, composed of a basal sheath with two deep incisions accompanied by a central pore, and an acicular end portion with smooth margins (Fig. 4E). Trunk cuticles around the insertion points of the spines on this and following segments with conspicuous subcuticular structures (Figs. 2E, F and 3A, B); most basal part of the spine inside the segments' cuticle shows spherical, condyle-like articulation, similar to a ball-and-socket articulation. Paired tubes present in lateroventral position (Figs. 2F, 3B and 4F); tubes on this and remaining segments short, flattened, stouter basally, distally with a median, longitudinal cleft surrounded by two flat, membranous wings (Fig. 4H). Two pairs of sensory spots in subdorsal position (Figs. 2E and 3A); paired sensory spots in ventrolateral, ventromedial and paraventral positions (Figs. 2F and 3B).

Segment 3 with paradorsal spine located to the left or to the right (Figs. 2E, 3A and 4A, D). Left or right displacement of paradorsal spines along the whole trunk varies 
216

217

218

219

220

221

222

223

224

225

226

227

228

229

230

231

232

233

234

235

236

237

238

239

240

241

242

243

244

245

246

among specimens (Figs. 2E, 3A and 4A) within the same population, and there are no apparent left/right preference correlated with sex or sampling location. Additional spines in lateroventral position (Figs. $2 \mathrm{~F}, 3 \mathrm{~B}$ and $4 \mathrm{~F}$ ); trunk cuticle around the insertion point of lateroventral acicular spines on this and following segments enforced, forming conspicuous subcuticular lines longitudinally directed (Figs. 2F and 3B). Unpaired sensory spots in middorsal and paradorsal positions, the latter located in a paradorsal position opposite to the side of the dorsal spine on the same segment (Figs. 2E and 3A); paired sensory spots in subdorsal, laterodorsal and ventrolateral positions (Figs. 2E-F and $3 \mathrm{~A}-\mathrm{B})$.

Segment 4 with paradorsal spine located on the opposite side of that on the preceding segment (Figs. 2E, 3A and 4A, D). Additional spines in lateroventral position (Figs. 2F, 3B and 4F). Unpaired sensory spots in middorsal and paradorsal positions, the latter located in a paradorsal position opposite to the side of the dorsal spine on the same segment (Figs. 2E and 3A); paired sensory spots in subdorsal, laterodorsal, ventrolateral and ventromedial positions (Figs. 2E-F, 3A).

Segment 5 with paradorsal spine located on the opposite side of that on the preceding segment (Figs. 2E and 3A). Additional spines in lateral accessory position (Figs. 2F, 3B and 4G-H). Paired tubes present in lateroventral position (Figs. 2F, 3B and 4G-H). Arrangement of sensory spots identical with segment 3 (Figs. 2E-F and 3A-B).

Segment 6 with paradorsal spine located on the opposite side of that on the preceding segment (Figs. 2E and 3A). In a single specimen, the paradorsal spines of this and the subsequent segment occurred on the same side (i.e., did not alternatingly shift sides), which is a deviation of the general morphological pattern of the species (Fig. 4A). Additional spines in lateroventral position (Figs. 2F, 3B and 4G, J). Arrangement of sensory spots identical with segment 3 (Figs. 2E-F and 3A-B).

Segment 7 similar to segment 4, except for the paradorsal spine and paradorsal sensory spot located on the opposite side of those on the segment 4 (Fig. 3A).

Segment 8 with paradorsal spine located on the opposite side of that on the preceding segment (Fig. 3A). Additional spines in lateroventral position (Figs. 2F, 3B and 4G, J). Paired tubes in laterodorsal position (Figs. 3A and 4J). Unpaired sensory spots in middorsal and paradorsal positions, the latter located in a paradorsal position 
opposite to the side of the dorsal spine on the same segment (Fig. 3A); paired sensory spots in subdorsal and ventrolateral positions (Figs. 2F and 3A-B).

Segment 9 with unpaired middorsal and paired lateroventral spines (Figs. 2F, 3A-B and 4A, G). Longitudinal cuticular ridges lacking dorsal, lateral and ventrally (Figs. 3A-B and 4A-B). Pair of sensory spots in paradorsal, subdorsal, laterodorsal, ventrolateral and ventromedial positions (Figs. 2F and 3A-B). Nephridiopores in lateral accessory positions (Fig. 3B); pore not sieve-like, formed by a minute, posteriorly directed opening with a few papillae.

Segment 10 lacking spines, with paired lateroventral tubes (Figs. 2G, 3B, D and 4K-L). Pair of sensory spots in paradorsal and subdorsal positions (Fig. 3A, C).

Segment 11 with lateral terminal spines (Figs. 2A, G, 3A-B and 4A-B, K-L). Gonopores of females not observed. Males with three pairs of penile spines; dorsal one longest, with very thick basis, smooth; medial one slightly shorter, attaching on the basis of the longest penile spine; ventral one shortest, crenulated, attaching on the outer lateral margin of the lateral terminal spine (Figs. 2H, 3C-D and 4L). Pair of sensory spots on the tips of the tergal extensions, giving these extensions a nipple-like appearance (Figs. 2G, 3A-D and 4K-L). Tergal extensions bulged, triangular, extending well beyond sternal plates (Figs. 2G, 3A-D and 4A-B, K-L); dorsal side of tergal extensions smooth (Fig. 3A, C), with ventral surface densely covered with short, papillary hairs (Figs. 3B, D and 4K-L). Posterior margins of sternal plates slightly rounded, without any projecting parts (Figs. 2G, 3B, D and 4K-L).

\subsection{Remarks on morphological features}

One of the examined specimens showed a modified alternate pattern of paradorsal spines, possessing three consecutive spines in the same side of the paradorsal position (Fig. 4A).

Two of the examined specimens carried ciliophoran epibionts attached to the laterodorsal surface of the segment 9 (Fig. 5A-B).

\subsection{Associated kinorhynch fauna}

Dracoderes spyro sp. nov. appeared together with Cristaphyes sp (Cepeda et al., in press), Cristaphyes cf. longicornis (Higgins, 1983), Echinoderes astridae Sørensen, 2014, Echinoderes sp (Cepeda et al., in press), Echinoderes spinifurca Sørensen et al., 
2782005 and Fujuriphyes sp (Cepeda et al., in press) in Puerto Blanco (L2); with

279 Cristaphyes sp in Isabela Bay (L3); with Fujuriphyes sp in Puerto Plata (L1); and with 280 Echinoderes sp in Cabo Haitiano (L4).

\section{Discussion}

\subsection{Taxonomy}

284 Dracoderes spyro sp. nov., clearly belongs to the genus Dracoderes by the combination of the following morphological features: mouth cone with 9 outer oral styles alternating in size between longer and shorter ones, neck consisting of nine placids with the dorsal and midlateral ones separated by cuticular folds, segment 1 of trunk composed of a ring cuticular plate and remaining segments composed of one tergal and two sternal cuticular plates, dorsal spines on segments 2-9 of which the first and the last ones appear in middorsal position and the remaining ones in paradorsal position alternatingly laterally displaced and males possessing three pairs of penile spines (Sørensen et al. 2012; Yamasaki, 2015). Dracoderes spyro sp. nov. can be easily distinguished from its congeners by the arrangement of the spines, tubes and the sensory spots locations, namely, having two pairs of subdorsal sensory spots on segment 1 and a single middorsal (perispinal) and paradorsal sensory spots on segments carrying paradorsal spines, whereas the remaining Dracoderes species possess one pair of subdorsal (if present in this position) sensory spots and a pair of perispinal sensory spots on segments carrying paradorsal spines (Sørensen et al. 2012; Thomsen et al. 2013; Yamasaki, 2015).

Regarding the nature and arrangement of spines/tubes, the recently described $D$. toyoshioae from Okinawa, Japan (northwest Pacific Ocean) shows most resemblance with $D$. spyro sp. nov. Nevertheless, the description of $D$. toyoshioae was based on a single adult female exoskeleton lacking most spines and tubes, only inferred by the presence of the respective subcuticular structures. Thus, the author assumed the nature of these spines/tubes, stating the need of additional specimens in order to better determine the morphological characters of this species (Yamasaki, 2015). Dracoderes toyoshioae is characterized by having lateroventral spines/tubes on segments 2-10, lateral accessory spines/tubes on segments 2-8, ventrolateral acicular spines on segment 1 and dorsal cuticular structures (possibly spines) on segments 1-9 (Yamasaki, 2015), 
while D. spyro sp. nov. also has lateroventral spines/tubes on segments 2-10 (tubes on segments 2, 5 and 10, and acicular spines on segments 3-4 and 6-9) but possesses lateral accessory spines only on segment 5, lacks ventrolateral acicular spines on segment 1 and has dorsal spines on segments 2-9. Furthermore, D. spyro sp. nov. possesses laterodorsal tubes on segment 8 which are absent in D. toyoshioae. The remaining congeners of the genus are characterized by having lateroventral spines/tubes on segments 5-9 or 5-10 (Adrianov and Malakhov, 1999; Sørensen et al. 2012; Thomsen et al. 2013; Yamasaki, 2015), while D. spyro sp. nov. also has lateroventral spines on segments 3 and 4. Another morphological feature that makes D. spyro sp. nov. easily recognizable, as previously mentioned, is the presence of laterodorsal tubes on segment 8 , which are absent in the remaining known congeners.

Based on the morphology of the posterior margin of segment 1, D. spyro sp. nov. is similar to D. abei, D. gallaicus and D. nidhug, having this margin strongly serrated and extending midventrally to form a triangular expansion. However, D. abei and D. gallaicus are characterized by having the posterior margin of segment 1 with rounded indentations (not serrated) from lateroventral to ventrolateral positions, whereas $D$. spyro sp. nov. and D. nidhug only have these rounded indentations in the lateroventral position. Furthermore, D. spyro sp. nov. also possesses the posterior margin of segment 2 extending midventrally to form a triangular extension, which is absent in D. abei, D. gallaicus and D. nidhug (Sørensen et al. 2012; Thomsen et al. 2013). On the other hand, D. orientalis and D. toyoshioae are characterized by having the posterior margin of segment 1 finely serrated, not extending midventrally (Adrianov and Malakhov, 1999; Yamasaki, 2015), whereas D. snufkini has long, extremely marked serrations on the ventral side (Yamasaki, 2015).

\subsection{Key to species of Dracoderes}

1 Middorsal subcuticular structure (possibly basal structure of spine) present on segment 1; ventrolateral spines on segment 1 present ... D. toyoshioae

- Middorsal subcuticular structure absent on segment 1; ventrolateral spines on segment 1 absent ... 2

2 Middorsal spine on segment 2 absent; subdorsal tubes present on segment $2 \ldots D$. nidhug 
341 - Middorsal spine on segment 2 present; subdorsal tubes absent on segment 2 ...3

3423 Lateroventral spines/tubes present on segments 2-10; laterodorsal tubes on segment 8 343 present ... D. spyro sp. nov

344 - Lateroventral spines/tubes present on some segments from 2 to 10 but never on 345 segments 3-4; laterodorsal tubes on segment 8 absent... 4

3464 Lateroventral tubes on segment 2 absent ... D. orientalis

347 - Lateroventral tubes on segment 2 present ... 5

3485 Lateral accessory spines present on segment 5 ... D. gallaicus

349 - Spines absent in lateral series on segment $5 \ldots 6$

3506 Lateroventral tubes on segment 10 absent; primary pectinate fringe of segment 1 351 strongly developed, with long, wide serrations on the ventral side not forming a V352 shaped extension... D. snufkini

353 - Lateroventral tubes on segment 10 present; primary pectinate fringe of segment 1 354 scarcely developed, with short, rounded serrations on the ventral side forming a V355 shaped

\subsection{Distribution of the genus}

357 Until the discovery of D. gallaicus, which was described from Galicia, northeastern 358 Spain, eastern Atlantic Ocean (Sørensen et al. 2012), the genus Dracoderes was thought 359 to be a kinorhynch taxon geographically limited to East Asia, as the only known species 360 were D. abei, from Mukaishima yacht harbor, Japan (Higgins and Shirayama, 1990) and 361 D. orientalis from Ulsan Bay, South Korea (Adrianov and Malakhov, 1999) (Fig. 1B, D). Later, additional three species of the genus were also described from the same area (Thomsen et al. 2013; Yamasaki, 2015), leaving D. gallaicus as the only Dracoderes species outside this area (Fig. 1B, D). With the description of D. spyro sp. nov. from Hispaniola Island, we extend the geographical distribution of the genus to American waters (Fig. 1A-C). Furthermore, this record marks the southernmost limit of the genus'

367 distribution, which is still unknown from the Southern Hemisphere (Fig. 1A-D).

\section{References}


370 Adrianov, A.V., Malakhov, V.V., 1999. Cephalorhyncha of the world ocean, first ed.

371 KMK Scientific Press, Moscow.

372 Artois, T., Fontaneto, D., McInnes, S., Todaro, M.A., Sørensen, M.V., Zullini, A., 2011.

373 Ubiquity of microscopic animals? Evidence from the morphological approach in species

374 identification, in: Fontaneto, D. (Ed.), Biogeography of Microscopic Organisms: Is

375 Everything Small Everywhere? Cambridge University Press, Cambridge. pp. 244-283.

376 Cepeda, D., Sánchez, N., Pardos, F., in press. First extensive account of the phylum

377 Kinorhyncha from Haiti and the Dominican Republic (Caribbean Sea), with the

378 description of four new species. Mar. Biodivers., in press.

379 Claparède, A.R.E., 1863. Zur Kenntnis der Gattung Echinoderes Duj. Beobachtungen 380 über Anatomie und Entwicklungsgeschichte wirbelloser Thiere an der Küste von 381 Normandie angestellt. Verlag von Wilhelm Engelmann, Leipzig.

382 Dal Zotto, M., Di Domenico, M., Garraffoni, A., Sørensen, M.V., 2013. Franciscideres 383 gen. nov. - a new, highly aberrant kinorhynch genus from Brazil, with an analysis of its 384 phylogenetic position. Syst. Biodivers. 11, 303-321. 385 https://doi.org/10.1080/14772000.2013.819045.

386 Higgins, R.P., 1964. Three new kinorhynchs from the North Carolina Coast. B. Mar. 387 Sci. 14, 479-493. https://doi.org/10.2307/3225864.

388 Higgins, R.P., 1969. Indian Ocean Kinorhyncha, 2: Neocentrophyidae, a new 389 homalorhagid family. P. Biol. Soc. Wash. 82, 113-128.

390 Higgins, R.P., 1983. The Atlantic Barrier reef ecosystem at Carrie Bow Cay, Belize, II: 391 Kinorhyncha. Smithson. Contrib. Mar. Sci. 18, 1-131. 392 https://doi.org/10.5479/si.01960768.18.1.

393 Higgins, R.P., 1988. Kinorhyncha, in: Higgins, R.P.; Thiel, H. (Eds.), Introduction to 394 the study of meiofauna. Smithsonian Institution Press, Washington D.C., pp. 328-331.

395 Higgins, R.P., Shirayama, Y., 1990. Dracoderidae, a new family of the cyclorhagid 396 Kinorhyncha from the Inland Sea of Japan. Zool. Sci. 7, 939-946.

397 Kirsteuer, E., 1964. Zur Kenntnis der Kinorhynchen Venezuelas. Zool. Anz. 173, 388398 393. 
399 Kozloff, E.N., 1972. Some aspects of development in Echinoderes (Kinorhyncha).

400 Trans. Am. Microscop. Soc. 91, 119-130. https://doi.org/10.2307/3225404.

401 Neuhaus, B., 2013. Kinorhyncha (=Echinodera), in: Schmidt-Rhaesa, A. (Ed.), 402 Handbook of Zoology, Gastrotricha, Cycloneuralia and Gnathifera, Volume 1 403 Nematomorpha, Priapulida, Kinorhyncha, Loricifera. De Gruyter, Hamburg, pp. 181404350.

405 Neuhaus, B., Pardos, F., Sørensen, M.V., Higgins, R.P., 2014. New species of 406 Centroderes (Kinorhyncha: Cyclorhagida) from the Northwest Atlantic Ocean, life 407 cycle and ground pattern of the genus. Zootaxa 3901, 1-69. 408 https://doi.org/10.11646/zootaxa.3901.1.1.

409 Pardos, F., Sánchez, N., Herranz, M., 2016. Two sides of a coin: the phylum 410 Kinorhyncha in Panama. I) Caribbean Panama. Zool. Anz. 265, 3-25. 411 https://doi.org/10.1016/j.jcz.2016.06.005.

412 Sánchez, N., Pardos, F., Sørensen, M.V., 2014. A new kinorhynch genus, Mixtophyes 413 (Kinorhyncha: Homalorhagida), from the Guinea Basin deep-sea, with new data on the 414 family Neocentrophyidae. Helgol. Mar. Res. 68, 221-239. 415 https://doi.org/10.1007/s10152-014-0383-6.

416 Sørensen, M.V., 2006. New kinorhynchs from Panama, with a discussion of some 417 phylogenetically significant cuticular structures. Meiofauna Marina 15, 51-77.

418 Sørensen, M.V., 2008. A new kinorhynch genus from the Antarctic deep sea and a new 419 species of Cephalorhyncha from Hawaii (Kinorhyncha: Cyclorhagida: Echinoderidae). 420 Org. Divers. Evol. 8, 230.e1-230.e18. https://doi.org/10.1016/j.ode.2007.11.003.

421 Sørensen, M.V., 2013. Phylum Kinorhyncha. Zootaxa 3703, 63-66. 422 https://doi.org/10.11646/zootaxa.3703.1.13.

423 Sørensen, M.V., 2014. First account of echinoderid kinorhynchs from Brazil, with the 424 description of three new species. Mar, Biodivers. 44, 251-274. 425 https://doi.org/10.1007/s12526-013-0181-4.

426 Sørensen, M.V., Dal Zotto, M., Rho, H.S., Herranz, M., Sánchez, N., Pardos, F., 427 Yamasaki, H., 2015. Phylogeny of Kinorhyncha based on morphology and two 
428 molecular loci. $\quad$ PLoS $\quad$ ONE $\quad 10, \quad$ e133440.

429 https://doi.org/10.1371/journal.pone.0133440.

430 Sørensen, M.V., Heiner, I., Ziemer, O., 2005. A new species of Echinoderes from 431 Florida (Kinorhyncha: Cyclorhagida). Proc. Biol. Soc. Wash. 118, 499-508. 432 https:/doi.org/10.2988/0006-324X(2005)118[499:ANSOEF]2.0.CO;2.

433 Sørensen, M.V., Herranz, M., Rho, H.S., Min, W.G., Yamasaki, H., Sánchez, N., 434 Pardos, F., 2012. On the genus Dracoderes Higgins \& Shirayama, 1990 (Kinorhyncha: 435 Cyclorhagida) with a redescription of its type species, D. abei, and a description of a 436 new species from Spain. Mar. Biol. Res. 8, 210-231. 437 https://doi.org/10.1080/17451000.2011.615328.

438 Sørensen, M.V., Pardos, F., 2008. Kinorhynch systematics and biology - an 439 introduction to the study of kinorhynchs, inclusive identification keys to the genera. 440 Meiofauna Marina 16, 21-73.

441 Thomsen, V.G., Rho, H.S., Kim, D., Sørensen, M.V., 2013. A new species of 442 Dracoderes (Kinorhyncha: Dracoderidae) from Korea provides further support for a 443 dracoderid-homalorhagid relationship. Zootaxa 3682, 133-142. 444 https://doi.org/10.11646/zootaxa.3682.1.6.

445 Yamasaki, H., 2015. Two new species of Dracoderes (Kinorhyncha: Dracoderidae) 446 from the Ryukyu Islands, Japan, with a molecular phylogeny of the genus. Zootaxa 447 3980, 359-378. https://doi.org/10.11646/zootaxa.3980.3.2.

448 Yamasaki, H., Hiruta, S.D., Kajihara, H., 2013. Molecular phylogeny of kinorhynchs. 449 Mol. Phylogenet. Evol. 67, 303-310. https://doi.org/10.1016/j.ympev.2013.02.016.

450 Yamasaki, H., Hiruta, S.D., Kajihara, H., Dick, M.H., 2014. Two kinorhynch species 451 (Cyclorhagida, Echinoderidae, Echinoderes) show different distribution patterns across 452 Tsugaru Strait, Northern Japan. Zool. Sci. 31, 421-429. 453 https://doi.org/10.2108/zs140011.

454 Zelinka, K., 1896. Demonstration von Tafeln der Echinoderes - Monographie. Verh. 455 Dtsch. Zool. Ges. 6, 197-199. 
458 We would like to thank Dr Jon Norenburg and Katie Ahlfeld for loaning the material

459 that made the present study possible.

460 FUNDING SOURCES

461 Cepeda was supported by a predoctoral fellowship of the Complutense University of

462 Madrid (CT27/16-CT28/16).

463 The authors declare no conflicts of interest.

464

465 TABLES

466 Table 1. Data on sampling localities and habitat of the collected specimens.

\begin{tabular}{|c|c|c|c|c|c|}
\hline $\begin{array}{l}\text { Station } \\
\text { code }\end{array}$ & Location & Geographical coordinates & Sampling date & Sediment & Depth (m) \\
\hline L1 & Puerto Plata, Dominican Republic & $\begin{array}{l}19^{\circ} 48^{\prime} 12^{\prime \prime} \mathrm{N} \\
70^{\circ} 42^{\prime} 00^{\prime \prime} \mathrm{W}\end{array}$ & $02 / 11 / 1980$ & Sandy mud & 5 \\
\hline $\mathrm{L} 2$ & $\begin{array}{l}\text { Puerto Blanco, } \\
\text { Dominican Republic }\end{array}$ & $\begin{array}{l}19^{\circ} 54^{\prime} 24^{\prime \prime} \mathrm{N} \\
70^{\circ} 56^{\prime} 24^{\prime \prime}\end{array}$ & 03/11/1980 & Silty mud & 3 \\
\hline L3 & Isabela Bay, Dominican Republic & $\begin{array}{l}19^{\circ} 53^{\prime} 18^{\prime \prime} \mathrm{N} \\
71^{\circ} 05^{\prime} 36^{\prime \prime} \mathrm{W}\end{array}$ & $04 / 11 / 1980$ & Silty mud & 4 \\
\hline $\mathrm{L} 4$ & Cabo Haitiano, Haiti & $\begin{array}{l}19^{\circ} 46^{\prime} 12^{\prime \prime} \mathrm{N} \\
72^{\circ} 11^{\prime} 00^{\prime \prime} \mathrm{W}\end{array}$ & $10 / 11 / 1980$ & Mud & $3-5$ \\
\hline L5 & Puerto Príncipe, Haiti & $18^{\circ} 32^{\prime} 21^{\prime \prime} \mathrm{N}$ & $15 / 03 / 1976$ & Mud & 5 \\
\hline
\end{tabular}

467

468 Table 2. Measurements of adult Dracoderes spyro sp. nov. from Hispaniola Island, 469 including number of measured specimens ( $n$ ), mean and standard deviation (SD).

470 Because there were no remarkable differences in sizes or dimensions between the two 471 sexes or sampling locations, measurements are not shown by sexes or populations.

472 Abbreviations: ac, acicular spine; LA, lateral accessory, LD, laterodorsal; LTS, lateral 473 terminal spine; LV, lateroventral spine/tube; MD, middorsal spine; MSW-5, maximum 474 sternal width (on segment 5); PD, paradorsal spine; S, segment lengths; SW-10, 475 standard width (on segment 10); TL, total length of trunk; tu, tube.

\begin{tabular}{lcc}
\hline \multicolumn{1}{c}{ Character } & Range & Mean $($ SD; $\boldsymbol{n})$ \\
\hline TL $(\mu \mathrm{m})$ & $158.8-275.3$ & $196.8(25.8 ; 34)$ \\
MSW-5 $(\mu \mathrm{m})$ & $47.8-63.9$ & $59.3(3.0 ; 34)$ \\
MSW-5/TL $(\%)$ & $22.6-33.6$ & $30.5(3.0 ; 34)$ \\
SW-10 $(\mu \mathrm{m})$ & $32.4-49.6$ & $43.4(5.0 ; 34)$
\end{tabular}




\begin{tabular}{|c|c|c|}
\hline SW-10/TL (\%) & $14.0-26.6$ & $22.4(3.6 ; 34)$ \\
\hline $\mathrm{S} 1(\mu \mathrm{m})$ & $28.7-37.6$ & $33.9(2.1 ; 34)$ \\
\hline $\mathrm{S} 2(\mu \mathrm{m})$ & $18.8-30.2$ & $27.0(2.9 ; 34)$ \\
\hline $\mathrm{S} 3(\mu \mathrm{m})$ & $18.8-33.4$ & $25.5(3.9 ; 34)$ \\
\hline $\mathrm{S} 4(\mu \mathrm{m})$ & $21.1-35.8$ & $31.8(4.0 ; 34)$ \\
\hline $\mathrm{S} 5(\mu \mathrm{m})$ & $24.5-37.9$ & $33.0(3.6 ; 34)$ \\
\hline $\mathrm{S} 6(\mu \mathrm{m})$ & $24.1-39.8$ & $33.2(3.9 ; 34)$ \\
\hline $\mathrm{S} 7(\mu \mathrm{m})$ & $22.2-38.8$ & $31.1(4.0 ; 34)$ \\
\hline $\mathrm{S} 8(\mu \mathrm{m})$ & $23.7-35.6$ & $28.9(3.0 ; 34)$ \\
\hline $\mathrm{S} 9(\mu \mathrm{m})$ & $20.0-37.2$ & $27.7(3.3 ; 34)$ \\
\hline $\mathrm{S} 10(\mu \mathrm{m})$ & $17.1-30.6$ & $25.7(3.0 ; 34)$ \\
\hline $\mathrm{S} 11(\mu \mathrm{m})$ & $18.8-30.5$ & $25.0(2.8 ; 34)$ \\
\hline MD $2(\mathrm{ac})(\mu \mathrm{m})$ & $15.9-36.4$ & $29.3(4.0 ; 34)$ \\
\hline PD $3(\mathrm{ac})(\mu \mathrm{m})$ & $21.7-37.9$ & $32.0(4.1 ; 34)$ \\
\hline PD $4(\mathrm{ac})(\mu \mathrm{m})$ & $19.7-41.9$ & $34.5(5.2 ; 34)$ \\
\hline PD $5(\mathrm{ac})(\mu \mathrm{m})$ & $26.4-45.2$ & $36.0(4.7 ; 34)$ \\
\hline PD $6(\mathrm{ac})(\mu \mathrm{m})$ & $14.9-38.7$ & $33.9(4.8 ; 33)$ \\
\hline PD $7(\mathrm{ac})(\mu \mathrm{m})$ & $23.7-41.6$ & $31.4(4.2 ; 33)$ \\
\hline PD $8(\mathrm{ac})(\mu \mathrm{m})$ & $17.6-34.4$ & $28.3(3.9 ; 32)$ \\
\hline $\operatorname{MD} 9(\mathrm{ac})(\mu \mathrm{m})$ & $20.9-34.1$ & $29.0(3.1 ; 30)$ \\
\hline LV $2(\mathrm{tu})(\mu \mathrm{m})$ & $5.5-13.2$ & $10.1(1.6 ; 34)$ \\
\hline LV $3(\mathrm{ac})(\mu \mathrm{m})$ & $14.7-26.6$ & $19.8(2.5 ; 34)$ \\
\hline LV 4 (ac) $(\mu \mathrm{m})$ & $14.0-26.0$ & $21.6(2.7 ; 34)$ \\
\hline LV $5(\mathrm{tu})(\mu \mathrm{m})$ & $6.3-15.7$ & $9.6(2.0 ; 34)$ \\
\hline LA $5(\mathrm{ac})(\mu \mathrm{m})$ & $18.9-29.0$ & $23.4(2.5 ; 34)$ \\
\hline LV $6(\mathrm{ac})(\mu \mathrm{m})$ & $17.4-28.6$ & $23.1(2.6 ; 34)$ \\
\hline LV 7 (ac) $(\mu \mathrm{m})$ & $16.4-29.9$ & $23.8(3.1 ; 34)$ \\
\hline LD $8(\mathrm{tu})(\mu \mathrm{m})$ & $5.1-9.9$ & $7.5(1.1 ; 20)$ \\
\hline $\operatorname{LV} 8(\mathrm{ac})(\mu \mathrm{m})$ & $18.5-31.5$ & $23.7(3.5 ; 34)$ \\
\hline $\operatorname{LV} 9(\mathrm{ac})(\mu \mathrm{m})$ & $16.2-30.5$ & $24.3(3.5 ; 34)$ \\
\hline LV $10(\mathrm{tu})(\mu \mathrm{m})$ & $6.0-11.3$ & $8.4(1.6 ; 20)$ \\
\hline $\operatorname{LTS}(\mu \mathrm{m})$ & $108.2-152.5$ & $130.8(9.7 ; 34)$ \\
\hline
\end{tabular}

477 Table 3. Summary of nature and arrangement of sensory spots, spines and tubes in 478 Dracoderes spyro sp. nov. Abbreviations: LA, lateral accessory; LD, laterodorsal; LV, 479 lateroventral; MD, middorsal; PD, paradorsal; PV, paraventral; SD, subdorsal; VL, 480 ventrolateral; VM, ventromedial; ac, acicular spine; lts, lateral terminal spine; m, male 481 condition of sexually dimorphic character; ne, nephridiopore; ps, penile spine; ss, 482 sensory spot; tu, tube; * indicates unpaired structures. 


\section{ACCEPTED MANUSCRIPT}

\begin{tabular}{lccccccccc}
\hline Segment & MD & PD & SD & LD & LA & LV & VL & VM & PV \\
\hline 1 & & & ss & ss ss & & & ss & ss & \\
& & & ss & & & & & & \\
2 & ac & & ss & & & tu & ss & ss & ss \\
& & & ss & & & & & & \\
3 & ss & ac* ss* & ss & ss & & ac & ss & & \\
4 & ss & ss*ac* & ss & ss & & ac & ss & ss & \\
5 & ss & $\mathrm{ac}^{*} \mathrm{ss}^{*}$ & ss & ss & ac & tu & ss & & \\
6 & ss & ss* ac* & ss & ss & & ac & ss & & \\
7 & ss & ac* ss* & ss & ss & & ac & ss & ss & \\
8 & ss & ss*ac* & ss & tu & & ac & ss & & \\
9 & ac & ss & ss & ss & ne & ac & ss & ss & \\
10 & & ss & ss & & & tu & & & \\
11 & & & ss & & & lts, psx3 (m) & & &
\end{tabular}

\section{FIGURE LEGENDS}

485

486

487

488

489

490

491

492

493

494

495

496

497

498

499

500

501

502

Fig. 1. Map showing the sampling locations of Dracoderes spyro sp. nov. in Hispaniola Island, Caribbean Sea, western Atlantic Ocean (A, C) and the distribution of the remaining species of the genus $(\mathrm{B}, \mathrm{D})$

Fig. 2. Light micrographs showing trunk overview and details in the head and the sexual dimorphism of female holotype USNM1480327 (A-G) and male paratype USNM140333 (H) of Dracoderes spyro sp. nov.. (A) Ventral overview of head and trunk; (B) Mouth cone, showing the outer oral styles; arrow indicates the median area bushy fringe tips; (C) Neck, showing the placids; arrowhead indicates cuticular folds; (D) Introvert, showing the scalids; arrow indicates the filiform fringes of the basal region; (E) middorsal, paradorsal, subdorsal and laterodorsal regions of tergal plates of segments 2-7 (F) lateroventral, ventrolateral and ventromedial regions of tergal and sternal plates of segments 2-10 (G) lateroventral, ventrolateral and ventromedial regions of tergal and sternal plates of segments 10-11; $(\mathrm{H})$ posterior end of the trunk, showing the sexually dimorphic male penile spines. Abbreviations: bp, basal part of outer oral style; hde, hook-like distal end of outer oral style; las, lateral accessory spine; lts, lateral terminal spine; lvs, lateroventral spine; lvt, lateroventral tube; mds, middorsal spine; pds, paradorsal spine; pl, placid; ps, penile spines; sbp, scalid basal part; sdp, scalid distal part; sus, subcuticular line; te, tergal extension; ts, trichoscalid; sensory 
503 spots are marked as dotted-line circles; numbers after abbreviation indicate the 504 corresponding segment.

505 Fig. 3. Line-art illustrations of Dracoderes spyro sp. nov. (A) Female, dorsal view; (B) 506 Female, ventral view; (C) Male, segments 10-11, dorsal view; (D) Male, segments 10507 11, ventral view. Abbreviations: cf, cuticular folding; las, lateral accessory spine; ld, 508 laterodorsal sensory spot; ldt, laterodorsal tube; lts, lateral terminal spine; lvs, 509 lateroventral spine; lvt, lateroventral tube; md, middorsal sensory spot; mds, middorsal 510 spine; ne, nephridial pore; pd, paradorsal sensory spot; pds, paradorsal spine; pl, placid; 511 ps, penile spines followed by penile spine number; pv, paraventral sensory spot; s, 512 segment followed by segment number; sd, subdorsal sensory spot; sus, subcuticular 513 line; te, tergal extension; tss, terminal sensory spot; vm, ventromedial sensory spot; vl, 514 ventrolateral sensory spot.

515 Fig. 4. Scanning electron micrographs showing overviews and details in the cuticular 516 trunk morphology of a non-type male (A, C-J and L) and a non-type female (B and K) 517 of Dracoderes spyro sp. nov. (A) Dorsal overview of trunk; (B) lateral and ventral 518 overviews of trunk; (C) introvert partially everted, showing some scalids; (D) middorsal 519 and paradorsal regions of tergal plates of segments 2-4; (E) detail of a paradorsal spine 520 of segment 3; (F) lateroventral, ventrolateral and ventromedial regions of tergal and 521 sternal plates of segments 1-4; (G) lateroventral, ventrolateral and ventromedial regions 522 of tergal and sternal plates of segments 5-9; $(\mathrm{H})$ detail of a lateroventral tube and a 523 lateral accessory spine of segment 5; (I) detail of subddorsal and laterodorsal sensory 524 spots of segments 2-3; (J) laterodorsal and lateroventral regions of tergal plates of 525 segments 6-8; (K) lateroventral, ventrolateral and ventromedial regions of tergal and 526 sternal plates of segments $10-11$ of a female; (L) lateroventral, ventrolateral and 527 ventromedial regions of tergal and sternal plates of segments 10-11 of a male. 528 Abbreviations: las, lateral accessory spine; ldt, laterodorsal tube; lts, lateral terminal 529 spine; lvt, lateroventral tube; lvs, lateroventral spine; mds, middorsal spine; pds, 530 paradorsal spine; ps, penile spine; te, tergal extension; ts, trichoscalid; sensory spots are 531 marked as dotted-line circles; numbers after abbreviations indicate the corresponding 532 segment.

533 Fig. 5. Light micrographs showing details of epibiontic Ciliophora on the cuticle surface of Dracoderes spyro sp. nov. on the laterodorsal position of segment 9. (A) Cuticle of segment 9 showing the attached epibionts; (B) Detail of a epibiont. 


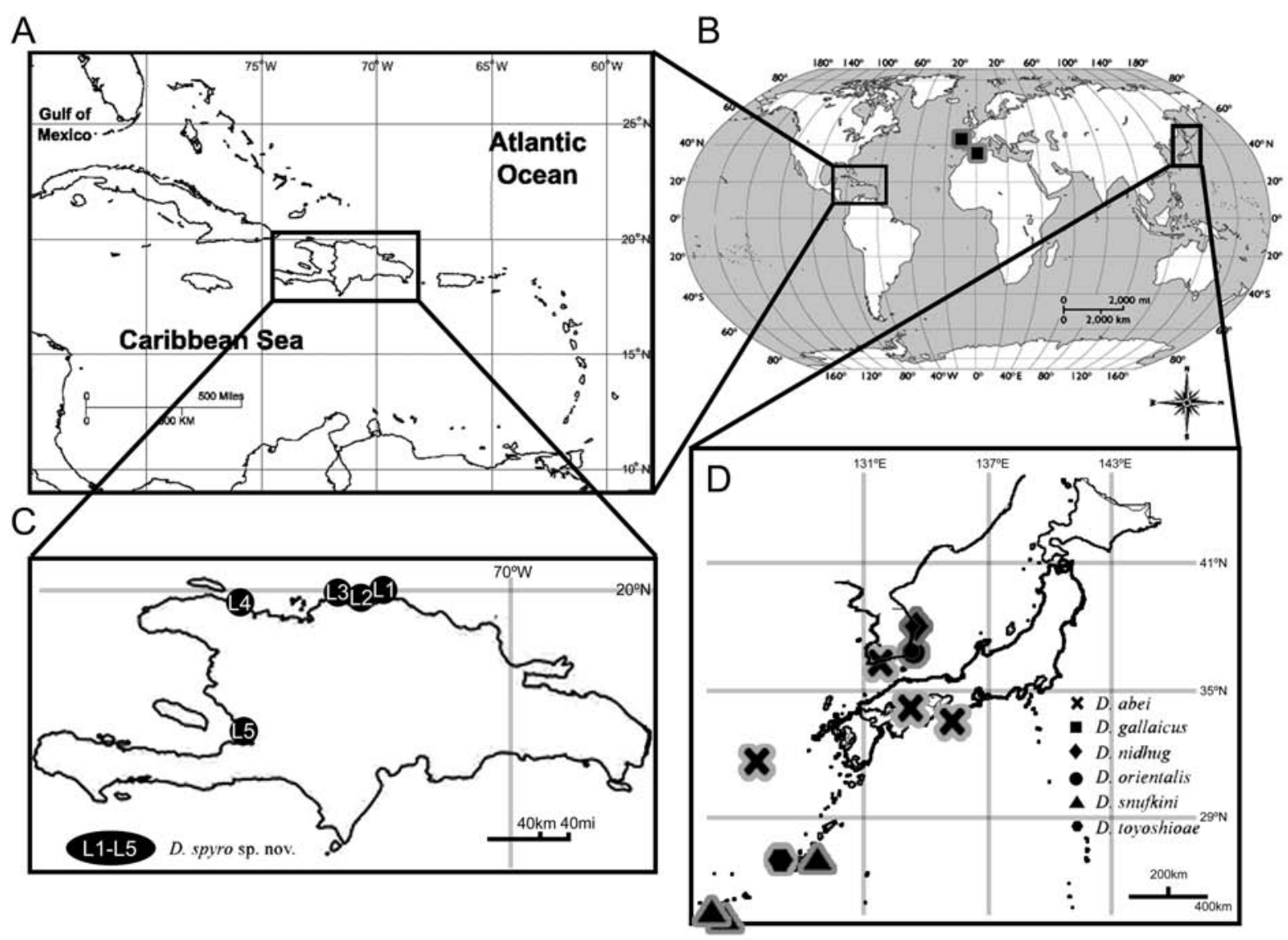




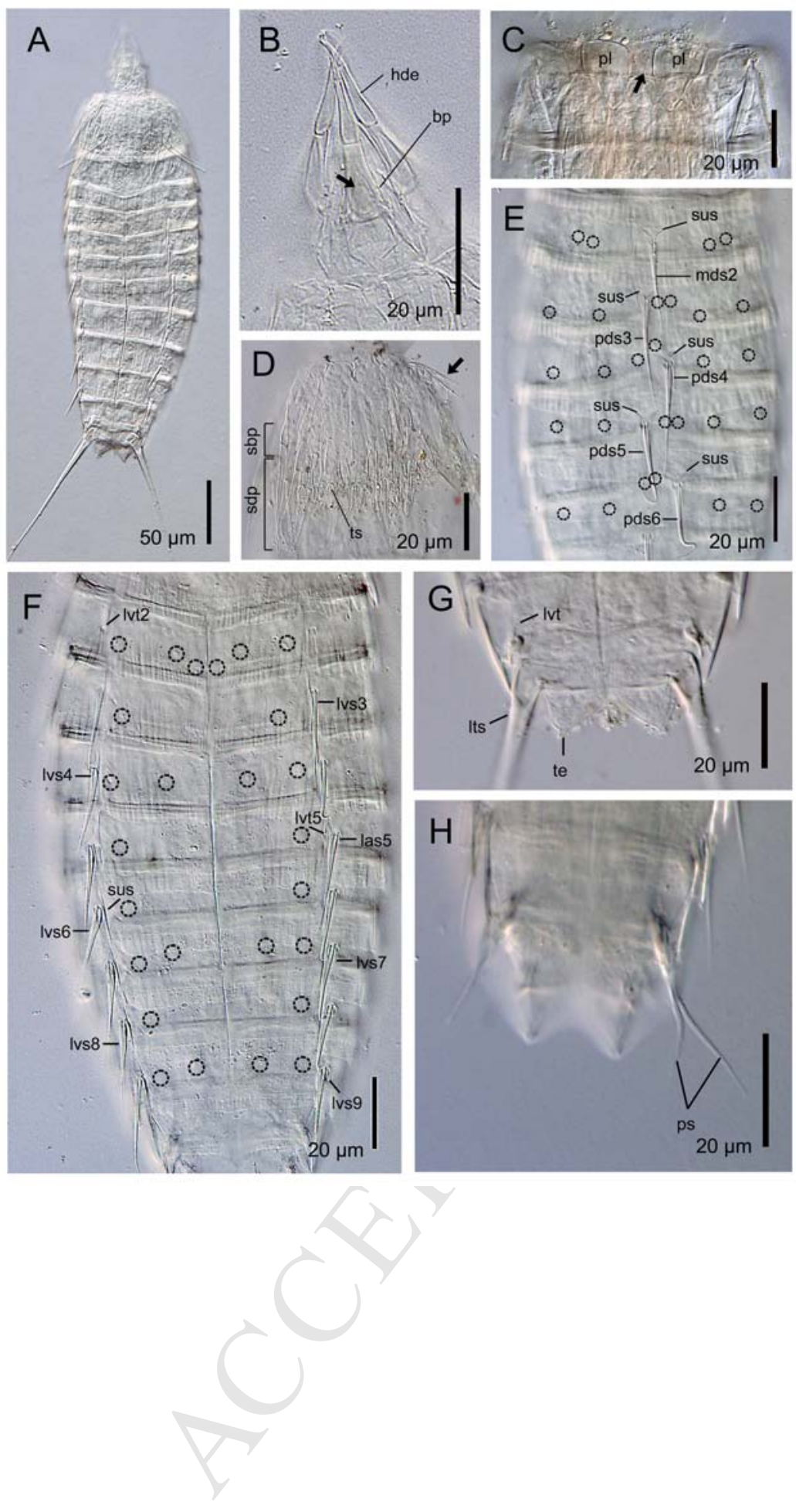




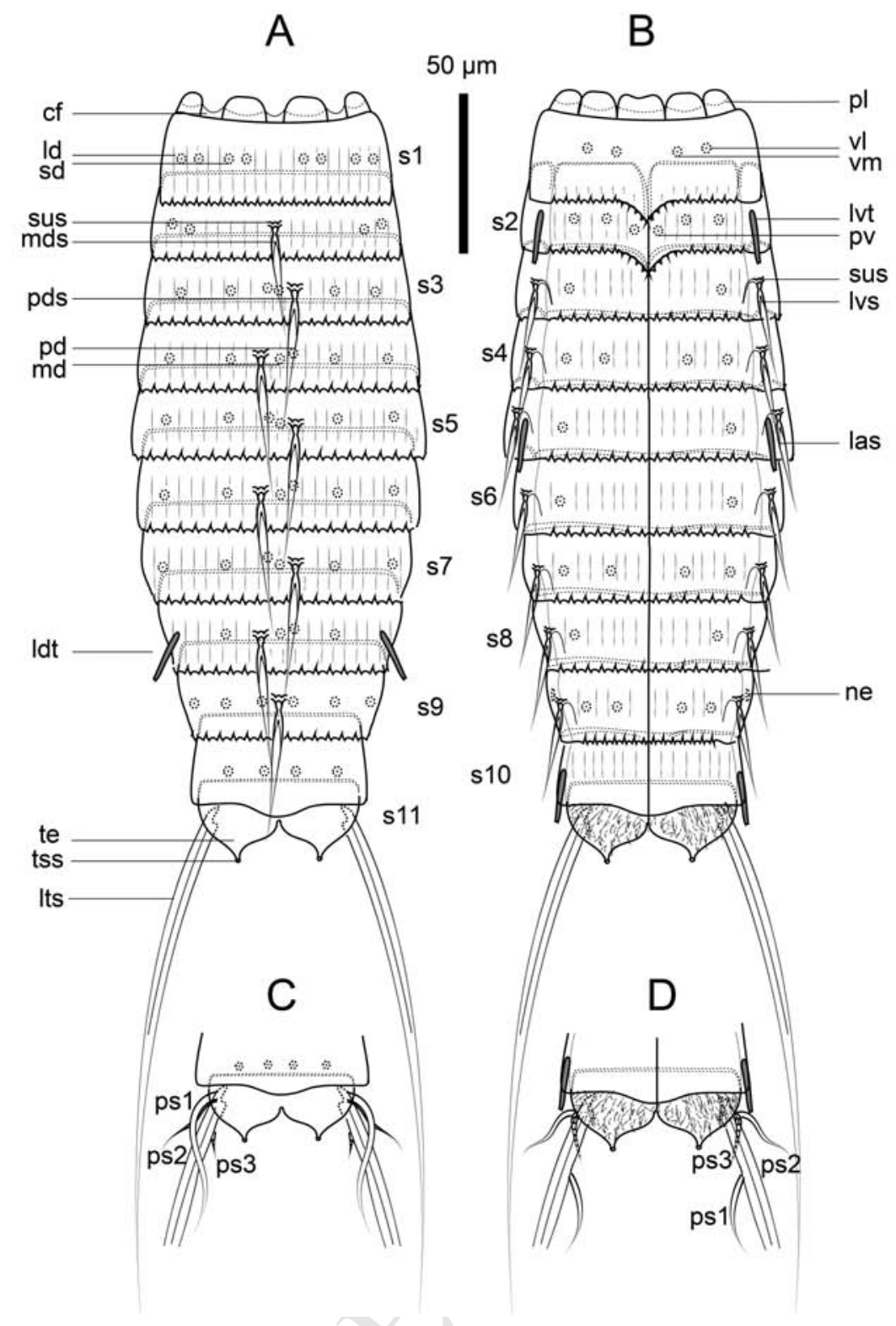



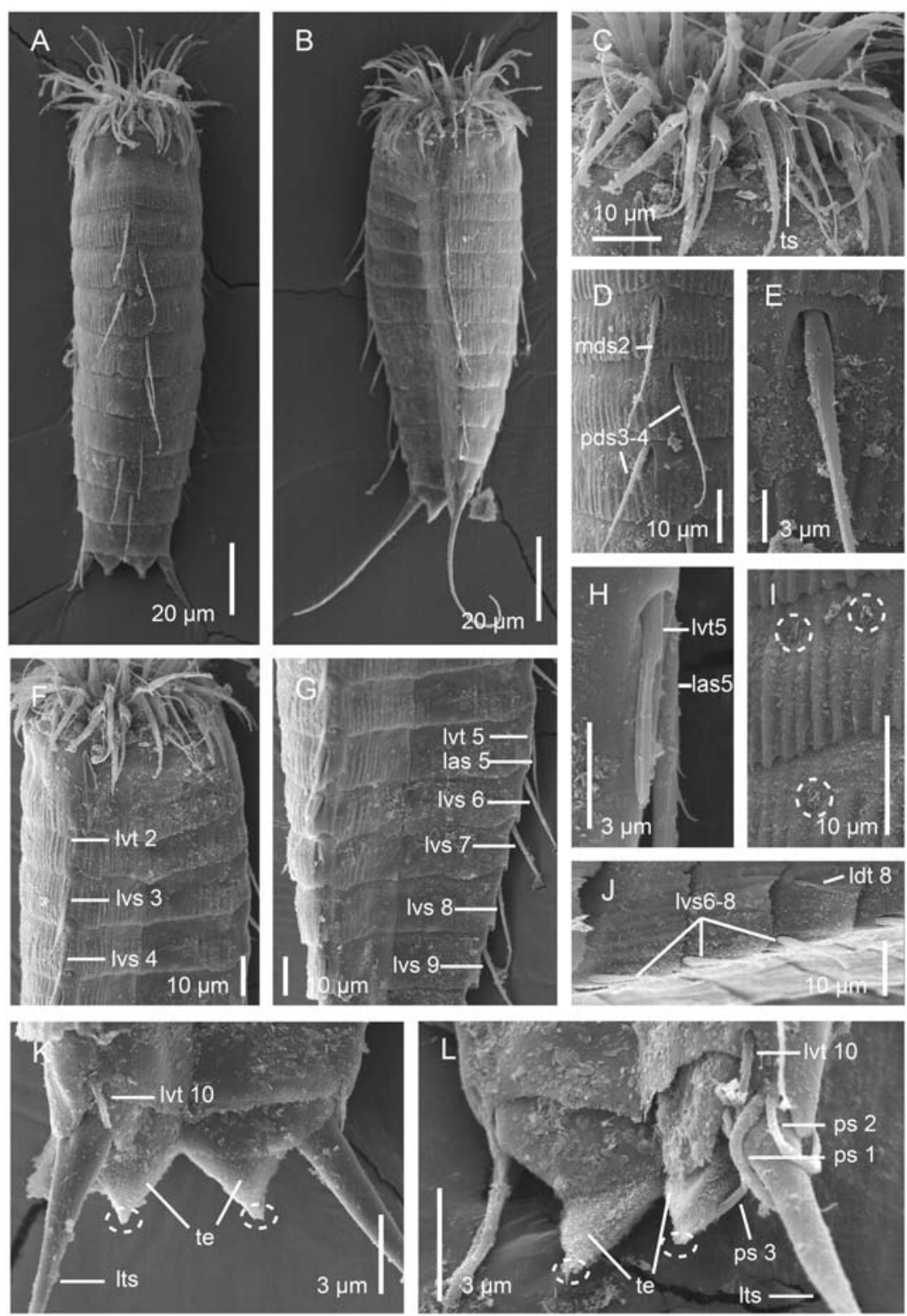

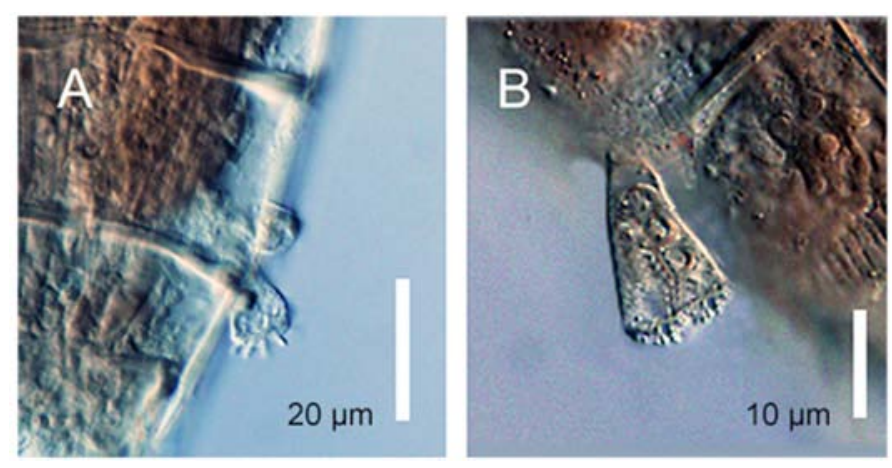